\title{
DAMPAK PANDEMI COVID-19 PADA PENDIDIKAN ANAK USIA DINI
}

\author{
Reni Amiliya ${ }^{1}$, Febri Giantara ${ }^{2}$ \\ Prodi PIAUD, Prodi PAI, STAI Diniyah Pekanbaru \\ reni@diniyah.ac.id, febri@diniyah.ac.id
}

\section{DOI: $10.46781 /$ al-abyadh.v4i2.385}

\begin{abstract}
Abstrak
Pandemi Covid-19 memberikan dampak yang begitu besar terhadap kehidupan manusia. Salah satu dampak Pandemi Covid-19 ialah penguncian dan penutupan semua aktivitas sosial disemua sektor mulai dari perusahaan hingga pada sektor pendidikan. Pada sektor pendidikan banyak terjadi penutupan layanan pendidikan pada awal pandemi sehingga pelaksanaan pendidikan dilakukan secara online dan di beberapa Negara menerapkan model pembelajaran blended-learning. Tujuan penelitian ini adalah memberikan gambaran secara jelas terkait dampak pandemi covid-19 pada Pendidikan Anak Usia Dini ditinjau dari berbagai perspektif. Metodologi pada penelitian ini Systematic Literature Review (SLR) untuk mendapatkan dan mengevaluasi berbagai literatur akademik yang tepat dan fokus pada topik tertentu. Hasil penelitian menunjukkan bahwa Pandemi Covid-19 berdampak pada pendidikan anak usia dini mulai dari anak, guru dan orang tua anak usia dini. Dampak dari Pandemi Covid-19 yang dirasakan pada seluruh elemen Pendidikan Anak Usia Dini ialah yang berkaitan dengan masalah psikologi.
\end{abstract}

Kata kunci: Pandemi Covid-19, Pendidikan Anak Usia Dini

\section{THE EFFECT OF AESTHETIC VALUES ON READING CORNER ARRANGEMENTS ON READING INTEREST IN EARLY CHILDREN}

\author{
Reni Amiliya ${ }^{1}$, Febri Giantara ${ }^{2}$ \\ Prodi PIAUD, Prodi PAI, STAI Diniyah Pekanbaru \\ reni@diniyah.ac.id, febrigiantara@diniyah.ac.id
}

\begin{abstract}
The Covid-19 pandemic has had a huge impact on human life. One of the impacts of the Covid-19 pandemic is the locking and closure of all social activities in all sectors, from companies to the education sector. In the education sector, there were many closures of educational services at the beginning of the pandemic, so that education was carried out online and in some countries a blended-learning model was applied. The purpose of this study is to provide a clear picture of the impact of the COVID-19 pandemic on early childhood education in terms of various perspectives. The methodology in this research is Systematic Literature Review (SLR) to obtain and evaluate various academic literatures that are appropriate and focused on certain topics. The results of the study show that the Covid-19 pandemic has an impact on early childhood education starting from children, teachers and parents of early childhood. The impact of the Covid-19 pandemic that is felt on all elements of Early Childhood Education is related to psychological problems.
\end{abstract}

Keywords: Pandemic Covid-19, Early Childhood Education 


\section{Pendahuluan}

Pandemi Covid-19 yang terjadi di seluruh dunia mengakibatkan perubahan dalam berbagai aspek kehidupan (Eriani \& Amiliya, 2020). Upaya pemerintah dalam mencegah penyebaran serta mengatasi Pandemi Covid-19 ini ialah dengan menerapkan lockdown atau peraturan bekerja dan belajar dari rumah sehingga pandemi Covid-19 yang terjadi memiliki dampak yang begitu besar pada kehidupan manusia. Pandemi Covid-19 berdampak pada seluruh sektor kehidupan manusia mulai dari sektor industry hingga sektor pendidikan. Pada sektor pendidikan, Pandemi Covid-19 berdampak hampir pada setiap jenjang pendidikan mulai dari tingkat tinggi seperti universitas hingga pendidikan dasar pada pendidikan anak usia dini.

Pada pendidikan anak usia dini, penerapan belajar dari rumah perlu mendapatkan perhatian yang serius (Munastiwi \& Puryono, 2021). Penerapan pelaksanaan pembelajaran dari rumah berdampak sangat besar pada Pendidikan Anak Usia Dini. Sejatinya pelaksanaan pembelajaran pada Pendidikan Anak Usia Dini atau cara belajar anak ialah anak belajar dengan melakukan kegiatan yang menantang (Bodrova, E., Germeroth, C., \& Leong, 2013), pembelajaran menggunakan benda konkrit (Miller, 1996: 54, Permendiknas Nomor 146 Tahun 2014) dan terutama ialah anak belajar secara aktif yang dilakukan dengan cara bermain (Child-, 2020; Den Hoed, 2014; Huang, 2013) Selain itu, anak juga membutuhkan interaksi sosial untuk mengembangkan keterampilan mereka (EM Lim, 2012, G. Keren \& M. Fridin, 2014). Melalui pengalaman terhadap kegiatan atau aktivitas bermainnya serta interaksi terhadap lingkungan sekitarnya tersebutlah anak belajar, sehingga hal tersebutlah yang akan menentukan bagaimana kualitas kehidupan mereka di masa depan (Mutia, 2010: 3, EA Donoghue \& C. On, 2017). Anak usia dini juga memiliki hak atas PAUD yang berkualitas, yang berarti menjaga hubungan yang stabil antara anak dengan orang dewasa atau orang tua, pengasuh, guru dan dengan teman sebaya (Child-, 2020; McKenna et al., 2021).

Mengingat betapa pentingnya hal tersebut, maka jelaslah bahwa Pandemi Covid-19 memiliki dampak yang cukup serius pada pendidikan anak usia dini. Dampak tersebut juga bukan hanya terjadi pada anak tetapi hampir terjadi pada keseluruhan elemen yang ada yaitu guru dan bahkan kepada orang tua. Dampak yang paling menonjol adalah masalah psikologi, baik itu yang terjadi pada anak, guru maupun orang tua (Eadie et al., 2021; J. H. Kim et al., 2021; Liu et al., 2021; McKenna et al., 2021; Park et al., 2020; Pattnaik \& Jalongo, 2021; Timmons et al., 2021; Tummala \& Muhammad, 2020). Berdasarkan beberapa penelitian yang ada dari dampak Pandemi Covid-19 pada masalah psikologi, maka peneliti tertarik untuk meneliti lebih dalam terkait "Dampak Pandemi Covid-19 Pada Pendidikan Anak Usia Dini”.

\section{Metode Penelitian}

Penelitian ini menggunakan metode Systematic Literature Review (SLR). Metode ini untuk mendapatkan dan mengevaluasi berbagai literatur akademik yang tepat dan fokus pada topik tertentu (Chalkiadaki, 2018; Suryani, 2014; Triandini et al., 2019). Penelitian ini ialah mencari jurnal-jurnal yang relevan terkait dampak pandemi covid-19 pada pendidikan anak usia dini. Metode ini dilaksanakan dengan 4 tahap yaitu pertama Research Question (RQ) atau pertanyaan penelitian yang berdasarkan topik yang akan diteliti. Selanjutnya dilakukan Search Process atau proses pencarian terhadap artikel atau jurnal yang sesuai dengan topik penelitian. Ketiga yaitu Research Question (RQ) Inclusion and Exclusion Criteria. untuk menentukan apakah topik yang diperoleh layak digunakan dan terakhir adalah Quality 
Assesment yang bertujuan untuk mengevaluasi terkait artikel dan jurnal yang telah ditemukan sesuai dengan topik penelitian.

\section{Hasil Penelitian dan Pembahasan}

Dunia telah mengalami berbagai pandemi kesehatan sebelum terjadinya wabah COVID-19. Yang membedakan pandemi ini dengan wabah lainnya ialah cakupan, durasi dan dampak. Sejak pertama kali merebaknya Pandemi COVID-19, virus ini telah menyebar hampir lebih dari 200 negara dan menginfeksi lebih dari 153 juta orang di seluruh dunia dengan lebih dari 3,5 juta kematian (Jackson, J. K., Weiss, M. A., Schwarzenberg, A. B., Nelson, R. M., Sutter, K. M., \& Sutherland, 2021). Pandemi Covid-19 ini merupakan sebuah pandemi kesehatan yang terjadi hampir di seluruh dunia, dimana pandemi kesehatan ini belum pernah terjadi sebelumnya dan berdampak disemua bidang kehidupan manusia termasuk pada sektor pendidikan di seluruh dunia (Zhu, X., \& Liu, 2020). Pemerintah menerapkan sistem lockdown atau pembatasan sosial secara besar-besaran pada setiap bidang untuk membatasi penyebaran Covid-19 ini.

Pembatasan sosial pada sektor selain pendidikan memunculkan dampak seperti masalah ekonomi (Esterwood, E., Saeed, 2020; Park et al., 2020; Suarez-Lopez et al., 2021), masalah pendidikan (Jalongo, 2021; Park et al., 2020; Yildırım, 2021), kesehatan (Jalongo, 2021; Suarez-Lopez et al., 2021), sosial (Ares, G., Bove, I., Vidal, L., Brunet, G., Fuletti, D., Arroyo, Á., \& Blanc, 2021; Bambra, C., Riordan, R., Ford, J., Matthews, 2020; Esposito, S., Principi, 2020; Esterwood, E., Saeed, 2020; Jalongo, 2021; Suarez-Lopez et al., 2021) dan psikologi (Jalongo, 2021; J. H. Kim et al., 2021; McKenna et al., 2021; Park et al., 2020; Suarez-Lopez et al., 2021; Timmons et al., 2021; Tummala \& Muhammad, 2020).
Pembatasan pada sektor pendidikan berlaku untuk setiap jenjang pendidikan termasuk pada jenjang prasekolah yaitu pada pendidikan anak usia dini. Pembatasan sosial ini berpengaruh besar pada pendidikan anak usia dini. Ada beberapa dampak yang timbul dari pemberlakuan lockdown pada setiap elemen yang ada di pendidikan anak usia dini. Dampak yang paling utama ialah kepada anak usia dini. Pembatasan sosial (lockdown) dikenal dengan: "TETAP DI RUMAH, TETAP AMAN" . Jika di telaah maka pada kata "AMAN" berarti bahwa jelas dan tepat bahwa di rumah dapat menghambat penyebaran virus dan infeksi. Namun, jika ditinjau dari sudut pandang lain, Pembatasan sosial (lockdown) pada Pandemi COVID-19 juga akan berdampak pada jenis 'keamanan' lainnya yaitu "keamanan dari cedera, terutama untuk anak-anak" (Palmer \& Teague, 2021; Suarez-Lopez et al., 2021). Hal ini bisa terjadi pada keluarga yang ada di desa dalam kasus di mana orang tua terus bekerja selama pandemi dan meninggalkan anak-anak mereka sehingga bisa mengakibatkan perilaku berisiko, dan cedera yang tidak disengaja (Esposito, S., Principi, 2020) atau cedera karena meningkatnya kekerasan dalam keluarga karena stress yang dialami oleh keluarga akibat Pandemi Covid-19 (Fegert, J.M., Vitiello, B., Plener, P.L., Clemens, 2020; Guessoum, S.B., Lachala, J., Radjacka, R., Carretiera, E., Minassiana, S., Benoita \& Moroa, n.d.; Liu, J.J., Bao, Y., Huang, X., Shi, J., Lu, n.d.; Sidpra, J., Abomeli, D., Hameed, B., Baker, J., Mankad, 2020; Usher K, Bhullar N, Durkin J, 2020).

Beberapa penelitian selanjutnya juga menjelaskan Pandemi Covid-19 juga berdampak pada kesehatan anak (Lafave et al., 2021; Yoshikawa, H., Wuermli, A., Britto, P., Dreyer, B., Leckman, J., Lye, S., Ponguta, L., Richter, L., \& Stein, 2020) diantara masalah tersebut adalah kesehatan fisik (Bahatheg, 2021; J. H. Kim et al., 
2021; Silliman Cohen, R.I., Bosk, 2020), obesitas bagi keluarga yang mampu maka keluarga menyimpan stok makanan olahan yang padat kalori, anak-anak menghabiskan lebih banyak waktu di dalam karena COVID-19 sehingga aktivitas fisik berkurang (Almandoz, J. P., Xie, L., Schellinger, J. N., Mathew, M. S., Gazda, C., Ofori, A., ... Messiah, 2020; Bahatheg, 2021; Rundle, A. G., Park, Y., Herbstman, J. B., Kinsey, E. W., \& Wang, 2020; Vrijheid, M., Fossati, S., Maitre, L., Márquez, S., Roumeliotaki, T., Agier, L., ... Chatzi, 2020) dan juga malnutrisi bagi keluarga yang kurang mampu (J. H. Kim et al., 2021).

Masalah selanjutnya ialah kognitif atau prestasi akademik (Cairns, M.R., Ebinger, M., Stinson, C., Jordan, 2020; J. H. Kim et al., 2021; Park et al., 2020; Y1ldırım, 2021; Yoshikawa, H., Wuermli, A., Britto, P., Dreyer, B., Leckman, J., Lye, S., Ponguta, L., Richter, L., \& Stein, 2020) dan terakhir masalah psikologi yang berkaitan dengan rasa cemas, stress, depresi, ganguan perhatian, perilaku dan emosional yang tidak terkontrol, komunikasi yang rendah dan kurangnya interaksi sosial dan kehilangan hubungan dengan teman-teman (Cairns, M.R., Ebinger, M., Stinson, C., Jordan, 2020; Chen, F., Zheng, D., Liu, J., Gong, Y., Guan, Z., Lou, 2020; Egan et al., 2021; Jiao, W.Y., Wang, L.N., Liu, J., Fang, S.F., Jiao, F.Y., Pettoello-Mantovani, M., 2020; J. H. Kim et al., 2021; Xie, X., Xue, Q., Zhou, Y., Zhu, K., Liu, Q., Zhang, J., 2020; Ye, 2020).

$$
\text { Pandemi Covid-19 selain }
$$

berdampak pada anak, juga berdampak pada pendidik. Beberapa penelitian menunjukkan bahwa pendidik mengalami kesulitan berurusan dengan Teknologi atau Internet seperti keterbatasan kemampuan guru dalam teknologi dan jaringan internet yang bermasalah (Alan, 2021; Dias, M. J. A., Almodóvar, M., Atiles, J. T., Vargas, A. C., \& León, n.d.; Jefrey, Szeftel, 2020; J. Kim, 2020; Munastiwi \& Puryono, 2021;
Park et al., 2020; Pattnaik \& Jalongo, 2021; Yildırım, 2021).

Penelitian lain menemukan dampak Pandemi Covid-19 terhadap kesejahteraan pendidik (Alan, 2021; Bassok, D., Markowitz, A. J., Smith, A., \& Kiscaden, n.d.; Eadie et al., 2021; Pramling Samuelsson et al., 2020; Swigonski et al., 2021). Kesejahteraan ini berkaitan dengan kelangsungan hidup sekolah mereka, kemungkinan pemotongan gaji atau tidak ada sisa gaji diakhir bulan, upah yang rendah bahkan sebelum pandemi dan kehilangan pekerjaan akibat pandemi. Hal tersebut tentu akan secara signifikan berpengaruh terhadap kualitas program pembelajaran dan kesejahteraan pendidik PAUD yang buruk memiliki implikasi yang signifikan bagi pembelajaran dan perkembangan anak-anak (Logan, H., Cumming, T., \& Wong, 2020).

Masalah psikologi menjadi masalah yang paling banyak dibahas dan ditemukan dari dampak Pandemi Covid-19. Masalah psikologis terkait kelelahan fisik akibat beban kerja yang berlebihan, kelelahan emosional karena kesulitan dalam mengembangkan komunikasi dengan orang tua dan tantangan dalam mengurangi kontak dengan orang tua serta pertemuan yang penuh tekanan dengan orang tua. Selanjutnya, masalah psikologi karena pendidik mengalami kesulitan menjangkau semua anak, tantangan dalam memberikan pengalaman pendidikan yang adil bagi anak-anak yang tidak memiliki computer atau akses ke Internet dan tantangan dalam mengelola perilaku anak-anak. Pendidik juga cemas karena takut resiko terpapar virus, stress karena beban kerja tinggi, mengalami kesulitan mengatur jadwal karena kegiatan pembelajaran tidak sesuai dengan jadwal yang direncanakan dan keterbatasan kemampuan dalam membuat konten pembelajaran selama belajar dari rumah. 
Penelitian lain juga menemukan dampak dari Pandemi Covid-19 tidak hanya terjadi pada anak, pendidik tapi juga bagi orang tua terutama orang tua anak usia dini. Selama aturan lockdown atau pembatasan sosial karena Pandemi Covid-19 ini dan menerapkan sistem belajar dari rumah, orang tua khawatir tentang anak-anak yang ketertinggalan dibidang akademis, terutama mengingat bahwa standar hasil yang semakin tinggi untuk prasekolah dan kelas dasar awal dan sumber belajar yang berorientasi pada anak serta kegiatan belajar di rumah antara orang tua dan anakanak dalam rumah tangga yang terbatas sehingga orang tua mendukung kembalinya anak-anak secara bertahap ke sekolah (J. H. Kim et al., 2021; Park et al., 2020; Pramling Samuelsson et al., 2020)

Efek atau dampak selanjutnya bagi keluarga yang tinggal di kota dengan orang tua yang bekerja di kantor maka mereka harus bekerja dari rumah atau Work From Home (WFH) dan harus mengurus anak mereka dan mengakibatkan beban ekstra atau kesulitan menyeimbangkan tuntutan pekerjaan dan rumah sehingga banyak orang tua yang mengalami stress sehingga melakukan pengabaian yang terkadang dapat membuat anak mengalami cidera yang tidak sengaja, pengabaian dalam merawat dan mendampingi anak selama belajar di rumah, melecehkan dan menerapkan hukuman saat anak melakukan kesalahan ((Balenzano, C., Moro, G., \& Girardi, 2020; Bassok, D., Markowitz, A. J., Smith, A., \& Kiscaden, n.d.; Bassok, D., Michie, M., Cubides-Mateus, D. M., Doromal, J. B., \& Kiscaden, n.d.; Crescentini, C., Feruglio, S., Matiz, A., Paschetto, A., Vidal, E., Cogo, P., Fabbro, 2020; Degli Espinosa, F., Metko, A., Raimondi, M., Impenna, M., \& Scognamiglio, 2020; Del Boca, D., Oggero, N., Profeta, P., \& Rossi, 2020; Gonzalez, K. E., Hanno, E. C., Cuartas, J., Jones, S. M., Lesaux, N. K., Hofer, K., Checkoway, A., \& Goodson, 2020; J. H. Kim et al., 2021;
Lagomarsino, F., Coppola, I., Parisi, R., \& Rania, 2020; Park et al., 2020; Tummala \& Muhammad, 2020).

Perlakuan yang diterima anak dari orang tua selama belajar dirumah akan sangat berdampak bagi psikologi anak baik dalam jangka pendek atau panjang. Meskipun, sistem lockdown atau pembatasan sosial diberhetikan dan anakanak kembali kesekolah namun hal tersebut belum pasti bisa menghilangkan trauma yang ada pada diri anak.

\section{Simpulan dan Saran}

Pandemi Covid-19 ini sangat berpengaruh pada pendidikan anak usia dini Penerapkan sistem lockdown atau pembatasan sosial terutama dengan penerapan belajar dari rumah memiliki banyak sekali dampak terhadap pertumbuhan dan perkembangan anak usia dini. Pemberlakuan tersebut berdampak hampir pada setiap aspek dan elemen yang ada pada pendidikan anak usia dini. Salah satu dampakdari pemberlakuan belajar dari rumah yaitu menyebabkan ganggguan psikologi bukan hanya pada anak tetapi pada pendidik dan orang tua. Permasalahan psikologi seperti trauma jangka panjang dapat mengganggu pertumbuhan dan perkembangan anak usia dini serta menurunkan prestasi belajar anak. Hal tersebut terjadi karena cara belajar anak usia dini berbeda dengan pembelajaran pada jenjang selanjutnya. Cara belajar anak usia dini diantaranya haruslah dilakukan dengan cara bermain dan melakukan aktivitas fisik secara langsung. Anak akan belajar secara langsung dari pengalamannya karena terlibat secara aktif selama kegiatan bermain dan dapat mengoptimalkan seluruh aspek perkembangan atau potensi yang dimilikinya.

Saran pada penelitian ini agar dilakukan penelitian lebih lanjut untuk membimbing pendidik dan orang tua untuk pendidikan anak usia dini yang berkelanjutan selama Pandemi Covid-19. 


\section{DAFTAR PUSTAKA}

Alan, Ü. (2021). Distance Education During the COVID-19 Pandemic in Turkey: Identifying the Needs of Early Childhood Educators. Early Childhood Education Journal, 49(5), 987-994. https://doi.org/10.1007/s10643-02101197-y

Almandoz, J. P., Xie, L., Schellinger, J. N., Mathew, M. S., Gazda, C., Ofori, A., ... Messiah, S. E. (2020). Impact of COVID-19 stay-at-home orders on weight-related behaviours among patients with obesity. Clinical Obesity. https://doi.org/10.1111/cob.12386.

Ares, G., Bove, I., Vidal, L., Brunet, G., Fuletti, D., Arroyo, Á., \& Blanc, M. V. (2021). The experience of social distancing for families with children and adolescents during the coronavirus (COVID-19) pandemic in Uruguay: Difculties and opportunities. Children and Youth Services.

Bahatheg, R. O. (2021). Young Children's Nutrition During the COVID-19 Pandemic Lockdown: A Comparative Study. Early Childhood Education Journal, 49(5), 915-923. https://doi.org/10.1007/s10643-02101192-3

Balenzano, C., Moro, G., \& Girardi, S. (2020). Families in the pandemic between challenges and opportunities: An empirical study of parents with preschool and school-age children. Italian Sociological Review.

Bambra, C., Riordan, R., Ford, J., Matthews, F. (2020). The COVID-19 pandemic and health inequalities. J. Epidemiol. Community Health. https://doi.org/10.1136/jech2020214401.
Bassok, D., Markowitz, A. J., Smith, A., \& Kiscaden, S. (n.d.). Child care leaders' experiences with COVID-19: First fndings from the study of early education in Louisiana. Curry.Virginia.Edu.

Bassok, D., Michie, M., Cubides-Mateus, D. M., Doromal, J. B., \& Kiscaden, S. (n.d.). The divergent experiences of early educators in schools and child care centers during COVID-19: Findings from Virginia. Panel presented at the 42nd Annual Association of Public Policy Analysis and Management.

Bodrova, E., Germeroth, C., \& Leong, D. (2013). Play and Self-Regulation: 170 Lessons from Vygotsky. American Journal of Play, 6(1), 111.

Cairns, M.R., Ebinger, M., Stinson, C., Jordan, J. (2020). COVID-19 and human connection: collaborative research on loneliness and online worlds from a sociallydistanced Academy. Hum. Organ., 281-291. https://doi.org/10.17730/1938- 352579.4.281

Chalkiadaki, A. (2018). 21st Century Skilss Journal. International Journal of Instruction, 11(3), 1-16.

Chen, F., Zheng, D., Liu, J., Gong, Y., Guan, Z., Lou, D. (2020). Depression and anxiety among adolescents during COVID-19: A cross-sectional study. Brain Behav Immun, 88, 36-38.

Child-, E. (2020). OMEP Position Paper: Early Childhood Education and Care in the Time of COVID-19. International Journal of Early Childhood, 52(2), 119-128. https://doi.org/10.1007/s13158-02000273-5 
Crescentini, C., Feruglio, S., Matiz, A., Paschetto, A., Vidal, E., Cogo, P., Fabbro, F. (2020). Stuck outside and inside: an exploratory study on the effects of the COVID-19 outbreak on Italian parents and Children's internalizing symptoms. Front. Psychol.

https://doi.org/10.3389/fpsyg.2020.586 074

Degli Espinosa, F., Metko, A., Raimondi, M., Impenna, M., \& Scognamiglio, E. (2020). A model of support for families of children with autism living in the Covid-19 lockdown: lessons from Italy. Behavioral Analysis and Practice, 13(3), 1-9.

Del Boca, D., Oggero, N., Profeta, P., \& Rossi, M. (2020). Women's and men's work, housework and childcare, before and during COVID-19. Review of Economics of the Household, 18, 101117.

Den Hoed, R. C. (Ed. ). (2014). Forest and Nature School in Canada: A Head Canada, Hands Approach to Outdoor Learning. Ottawa: Forest School.

Dias, M. J. A., Almodóvar, M., Atiles, J. T., Vargas, A. C., \& León, I. M. Z. (n.d.). Rising to the Challenge: innovative early childhood teachers adapt to the COVID-19 era. Childhood Education. https://doi.org/10.1080/00094056.2020 .1846385

Eadie, P., Levickis, P., Murray, L., Page, J., Elek, C., \& Church, A. (2021). Early Childhood Educators' Wellbeing During the COVID-19 Pandemic. Early Childhood Education Journal, 49(5), 903-913. https://doi.org/10.1007/s10643-02101203-3

Egan, S. M., Pope, J., Moloney, M., Hoyne,
C., \& Beatty, C. (2021). Missing Early Education and Care During the Pandemic: The Socio-Emotional Impact of the COVID-19 Crisis on Young Children. Early Childhood Education Journal, 49(5), 925-934. https://doi.org/10.1007/s10643-02101193-2

Eriani, E., \& Amiliya, R. (2020). Mitra Ash-Shibyan Blended Learning: Kombinasi Belajar Untuk Anak Usia Dini. Jurnal Pendidikan Dan Konseling, 03(01), 11-21.

Esposito, S., Principi, N. (2020). . School closure during the coronavirus disease 2019 (COVID-19) pandemic: an effective intervention at the global level? JAMA Pediatrics. https://doi.org/10.1001/jamapediatrics. 2020.1892 .

Esterwood, E., Saeed, S. . (2020). Past epidemics, natural disasters, COVID19, and mental health: learning from history as we deal with the present and prepare for the future. Psychiatry $Q$. https://doi.org/10.1007/s11126-02009808-4.

Fegert, J.M., Vitiello, B., Plener, P.L., Clemens, V. (2020). Challenges and burden of the coronavirus 2019 (COVID-19) pandemic for child and adolescent mental health: a narrative review to highlight clinical and research needs in the acute phase and the long return to normality. Child Adolesc. Psychiatry Mental Health.

Gonzalez, K. E., Hanno, E. C., Cuartas, J., Jones, S. M., Lesaux, N. K., Hofer, K., Checkoway, A., \& Goodson, B. (2020). How are they faring? Impacts of the COVID-19 pandemic on the lives of families and young children in Massachusetts. Saul Zaentz Early 
Education Initiative, Harvard Graduate School of Education.

Guessoum, S.B., Lachala, J., Radjacka, R., Carretiera, E., Minassiana, S., Benoita, L., \& Moroa, M. R. (n.d.). Adolescent psychiatric disorders during the COVID-19 pandemic and lockdown. Psychiatry Res. https://doi.org/10.1016/j.\%0APsychres .2020 .113264 .

Huang, R. (2013). What Can ChildrenLearn Through Play? Chinese Parents' Iti, Perspective of Play and Learning in Early Childhood Education. Te Kahurangi, School of Education eJounal, 1(12).

Jackson, J. K., Weiss, M. A., Schwarzenberg, A. B., Nelson, R. M., Sutter, K. M., \& Sutherland, M. D. (2021). Global economic efects of COVID-19. Congressional Research Service.

Jalongo, M. R. (2021). The Effects of COVID-19 on Early Childhood Education and Care: Research and Resources for Children, Families, Teachers, and Teacher Educators. Early Childhood Education Journal, 49(5), 763-774. https://doi.org/10.1007/s10643-02101208-y

Jefrey, Szeftel, H. (2020). Supporting Head Start Employee Well-Being During the COVID-19 Pandemic. JAACP.

Jiao, W.Y., Wang, L.N., Liu, J., Fang, S.F., Jiao, F.Y., Pettoello-Mantovani, M., et al. (2020). Behavioral and emotional disorders in children during the COVID-19 epidemic. Pediatrics.

Kim, J. (2020). Learning and Teaching Online During Covid-19: Experiences of Student Teachers in an Early
Childhood Education Practicum. International Journal of Early Childhood, 52(2), 145-158. https://doi.org/10.1007/s13158-02000272-6

Kim, J. H., Araya, M., Hailu, B. H., Rose, P. M., \& Woldehanna, T. (2021). The Implications of COVID-19 for Early Childhood Education in Ethiopia: Perspectives from Parents and Caregivers. Early Childhood Education Journal, 49(5), 855-867. https://doi.org/10.1007/s10643-02101214-0

Lafave, L., Webster, A. D., \& McConnell, C. (2021). Impact of COVID-19 on Early Childhood Educator's Perspectives and Practices in Nutrition and Physical Activity: A Qualitative Study. Early Childhood Education Journal, 49(5), 935-945. https://doi.org/10.1007/s10643-02101195-0

Lagomarsino, F., Coppola, I., Parisi, R., \& Rania, N. (2020). Care tasks and new routines for Italian families during the COVID-19 pandemic: Perspectives from women. Italian Sociological Review, 10(3S), 847-868.

Liu, J.J., Bao, Y., Huang, X., Shi, J., Lu, L. (n.d.). Mental health considerations for children quarantined because of COVID-19. Lancet Child Adolesc Health 4, 347-349.

Liu, Y., Yue, S., Hu, X., Zhu, J., Wu, Z., Wang, J. L., \& Wu, Y. (2021). Associations between feelings/behaviors during COVID-19 pandemic lockdown and depression/anxiety after lockdown in a sample of Chinese children and adolescents. Journal of Affective Disorders, 284(January), 98-103. https://doi.org/10.1016/j.jad.2021.02.0 
01

Logan, H., Cumming, T., \& Wong, S. (2020). Sustaining the workrelated wellbeing of early childhood educators: Perspectives from International, key stakeholders in early childhood organisations. Journal of Early Childhood, 52, 95-113.

McKenna, M., Soto-Boykin, X., Cheng, K., Haynes, E., Osorio, A., \& Altshuler, J. (2021). Initial Development of a National Survey on Remote Learning in Early Childhood During COVID19: Establishing Content Validity and Reporting Successes and Barriers. Early Childhood Education Journal, 49(5), $815-827$. https://doi.org/10.1007/s10643-02101216-y

Munastiwi, E., \& Puryono, S. (2021). Unprepared management decreases education performance in kindergartens during Covid-19 pandemic. Heliyon, 7(5), e07138. https://doi.org/10.1016/j.heliyon.2021. $\mathrm{e} 07138$

Palmer, C. S., \& Teague, W. J. (2021). Childhood injury and injury prevention during COVID-19 lockdown - stay home, stay safe? Injury, 52(5), 1105-1107. https://doi.org/10.1016/j.injury.2021.0 4.032

Park, E., Logan, H., Zhang, L., Kamigaichi, N., \& Kulapichitr, U. (2020). Responses to Coronavirus Pandemic in Early Childhood Services Across Five Countries in the Asia-Pacific Region: OMEP Policy Forum. International Journal of Early Childhood, 52(3), 249-266.

https://doi.org/10.1007/s13158-02000278-0
Pattnaik, J., \& Jalongo, M. R. (2021). Early Childhood Education and Care in the Time of COVID-19: Introduction to a Special Issue of Early Childhood Education Journal. Early Childhood Education Journal, 49(5), 757-762. https://doi.org/10.1007/s10643-02101220-2

Pramling Samuelsson, I., Wagner, J. T., \& Eriksen Ødegaard, E. (2020). The Coronavirus Pandemic and Lessons Learned in Preschools in Norway, Sweden and the United States: OMEP Policy Forum. International Journal of Early Childhood, 52(2), 129-144. https://doi.org/10.1007/s13158-02000267-3

Rundle, A. G., Park, Y., Herbstman, J. B., Kinsey, E. W., \& Wang, Y. C. (2020). (2020). COVID-19-related school closings and risk of weight gain among children. Obesity, 28(6), 10081009.

https://doi.org/10.1002/oby.22813

Sidpra, J., Abomeli, D., Hameed, B., Baker, J., Mankad, K. (2020). Rise in the incidence of abusive head trauma during the COVID-19 pandemic. Arch. Dis. Child.

Silliman Cohen, R.I., Bosk, E. A. (2020). Vulnerable youth and the COVID-19 pandemic. Pediatrics.

Suarez-Lopez, J. R., Cairns, M. R., Sripada, K., Quiros-Alcala, L., Mielke, H. W., Eskenazi, B., Etzel, R. A., \& Kordas, K. (2021). COVID-19 and children's health in the United States: Consideration of physical and social environments during the pandemic. Environmental Research, 197(December 2020). https://doi.org/10.1016/j.envres.2021.1 11160 
Suryani, L. and M. (2014). "Metode SLR untuk Mengidentifikasi Isu-Isu dalam Software Engineering. " SATIN (Sains Dan Teknol. Informasi), 3(1).

Swigonski, N. L., James, B., Wynns, W., \& Casavan, K. (2021). Physical, Mental, and Financial Stress Impacts of COVID-19 on Early Childhood Educators. Early Childhood Education Journal, 49(5), 799-806. https://doi.org/10.1007/s10643-02101223-z

Timmons, K., Cooper, A., Bozek, E., \& Braund, H. (2021). The Impacts of COVID-19 on Early Childhood Education: Capturing the Unique Challenges Associated with Remote Teaching and Learning in K-2. Early Childhood Education Journal, 49(5), 887-901. https://doi.org/10.1007/s10643-02101207-z

Triandini, E., Jayanatha, S., Indrawan, A., Werla Putra, G., \& Iswara, B. (2019). Metode Systematic Literature Review untuk Identifikasi Platform dan Metode Pengembangan Sistem Informasi di Indonesia. Indonesian Journal of Information Systems, 1(2), 63.

https://doi.org/10.24002/ijis.v1i2.1916

Tummala, P., \& Muhammad, T. (2020). Conclusion for Special Issue on COVID-19: How can we better protect the mental health of children in this current global environment? Child Abuse and Neglect, 110(P2), 104808. https://doi.org/10.1016/j.chiabu.2020.1 04808

Usher K, Bhullar N, Durkin J, et al. (2020). . Family violence and COVID-19: Increased vulnerability and reduced options for support. International Journal Mental Health Nurs.
https://doi.org/DOI:10.1111/inm.1273 5

Vrijheid, M., Fossati, S., Maitre, L., Márquez, S., Roumeliotaki, T., Agier, L., ... Chatzi, L. (2020). Early-life environmental exposures and childhood obesity: An exposomewide approach. Environmental Health Perspectives.

Xie, X., Xue, Q., Zhou, Y., Zhu, K., Liu, Q., Zhang, J., et al. (2020). Mental health status among children in home confinement during the coronavirus disease 2019 outbreak in hubei province, China. JAMA Pediatrics.

Ye, J. (2020). Pediatric mental and behavioral health in the period of quarantine and social distancing with COVID-19. JMIR Pediatr Parent.

Y1ldırım, B. (2021). Preschool Education in Turkey During the Covid-19 Pandemic: A Phenomenological Study. Early Childhood Education Journal, 49(5), 947-963. https://doi.org/10.1007/s10643-02101153-w

Yoshikawa, H., Wuermli, A., Britto, P., Dreyer, B., Leckman, J., Lye, S., Ponguta, L., Richter, L., \& Stein, A. (2020). Efects of the global COVID19 pandemic on early childhood development: Short- and long-term risks and mitigating program and policy actions. The Journal of Pediatrics, 223(1), 188-193.

Zhu, X., \& Liu, J. (2020). (2020). Education in and after COVID-19: Immediate responses and long-term visions. Postdigital Science and Education, 23, 695-699. https://link.springer.com/content/pdf/ 10.1007/s42438-020-00126-3.pdf 
Dampak Pandemi Covid-19 pada Pendidikan...- 126

Reni Amiliya, Febri Giantara 